(c) American Dairy Science Association, 2003.

\title{
Composition and Functional Capacity of Blood Mononuclear Leukocyte Populations from Neonatal Calves on Standard and Intensified Milk Replacer Diets ${ }^{1}$
}

\author{
B. J. Nonnecke, ${ }^{*}$ M. R. Foote,$\dagger^{, 2}$ J. M. Smith, $\dagger$ B. A. Pesch, ${ }^{\star}$ \\ and M. E. Van Amburght \\ *Periparturient Diseases of Cattle Research Unit, \\ USDA, ARS, National Animal Disease Center, Ames 50010 \\ †Department of Animal Science, Cornell University, Ithaca 14583-4801
}

\begin{abstract}
Effects of increased dietary energy and protein on the composition and functional capacities of blood mononuclear leukocyte populations from milk replacer-fed calves were investigated. Holstein bull calves (average age: $4.2 \mathrm{~d} ; \mathrm{n}=19$ ) were assigned randomly to one of two treatment groups. Treatment 1 calves $(n=9)$ were fed a $20 \%$ crude protein, $20 \%$ fat milk replacer at a rate of $1.4 \%$ body weight of dry matter/d for $8 \mathrm{wk}$, whereas treatment 2 calves $(n=10)$ were fed a $30 \%$ crude protein, $20 \%$ fat milk replacer at a rate of $2.5 \%$ body weight of dry matter per day. Composition and functional capacities of mononuclear leukocyte populations from blood samples collected at $4,18,32,46$, and $60 \mathrm{~d}$ of age were characterized by flow cytometry and ex vivo cell function assays. From 11 to $60 \mathrm{~d}$ of age, the mean daily weight gain of treatment 2 calves $(1.20 \mathrm{~kg} / \mathrm{d})$ was greater than daily weight gain of treatment 1 calves $(0.55 \mathrm{~kg} / \mathrm{d})$. At $60 \mathrm{~d}$ of age, the mean body weight of treatment two calves was $53 \%(39 \mathrm{~kg})$ greater than the mean body weight of treatment 1 calves. Total numbers of blood leukocytes and the composition of the mononuclear leukocyte population were unaffected by the plane of nutrition. Mitogen-induced DNA-synthesis and immunoglobulin $\mathrm{M}$ secretion also were unaffected by dietary treatment. Blood mononuclear leukocytes from calves on intensified diets, however, produced less interferon- $\gamma$ and more inducible nitric oxide, suggesting that increased dietary energy and protein affects spe-
\end{abstract}

Received April 17, 2003.

Accepted June 16, 2003.

Corresponding author: B. J. Nonnecke; e-mail: bnonneck@nadc. ars.usda.gov.

${ }^{1}$ Names of products are necessary to report factually on available data; however, the USDA neither guarantees nor warrants the standard of the product, and use of the name by the USDA implies no approval of the product to the exclusion of others that may also be suitable.

${ }^{2}$ Current address: Department of Animal Sci., Iowa State University, Ames, IA. cific aspects of leukocyte function associated with cellmediated immunity. The impact of altered interferon$\gamma$ and NO production on the calf's susceptibility to infectious disease are not known. Mononuclear leukocyte populations from all calves also demonstrated age-related changes in composition and functional capacity, likely reflecting natural exposure to infectious agents and maturation of the calf's immune system.

(Key words: developmental immunity, interferon, neonatal calf nutrition, nitric oxide)

Abbreviation key: ConA = concanavalin A, FBS = fetal bovine serum, IFN = interferon, IL-2r $=$ interleukin-2 receptor, $\mathbf{M H C}=$ major histocompatibility complex, $\mathbf{M R}=$ milk replacer, $\mathbf{P B M C}=$ peripheral blood mononuclear cell, $\mathbf{P W M}$ = pokeweed mitogen, $\mathbf{T R T}=$ treatment.

\section{INTRODUCTION}

The neonatal calf has a heightened susceptibility to a variety of infectious diseases. The developmental immaturity of the neonate's immune system is considered contributory to its increased susceptibility. Peripheral blood mononuclear cells (PBMC) from 1-wk-old calves fed colostrum and milk are functionally hyporesponsive when compared to PBMC from adult cattle (Rajaraman et al., 1997). The capacity of PBMC from young calves to produce inducible NO, a component of bactericidal mechanisms of phagocytic leukocytes, and interferon (IFN)- $\gamma$, a pivotal cytokine in cell-mediated immunity, differ substantially from the capacities of PBMC from adult cattle (Rajaraman et al., 1997, 1998). Other functional differences include decreased antibody production (Nagahata et al., 1991), reduced secretion of other cytokines (Nonnecke et al., 2003), and reduced neutrophil function (Dore et al., 1991; Higuchi et al., 1997). The composition of PBMC populations in young calves also differs markedly from adult populations. Blood mononuclear leukocyte populations from newborn calves are characterized by a higher proportion of $\gamma \delta \mathrm{T}$ 
cells (Wyatt et al., 1994; Wilson et al., 1996; Rajaraman et al., 1997; Nonnecke et al., 1999) and a lower proportion of B cells (Senogles et al., 1978; Nonnecke et. al., 1999). These age-related differences in PBMC populations likely contribute to the increased susceptibility of the neonatal calf to infectious disease.

Results from a recent series of studies indicate that body composition of Holstein calves can be manipulated by diet and that the nutrient requirements of the young calf have not been well described (Bartlett, 2001; Blome, 2001; Diaz et al., 2001; Tikofsky et al., 2001). Standard milk replacer (MR) formulations and feeding rates as described on feed tags do not provide sufficient nutrients for the calf to achieve its growth potential or during certain periods of the year meet maintenance requirements. Nutritional insufficiency also may impact immune function and infectious disease susceptibility. Nutrition is a critical determinant of immune responses with protein-energy balance influencing cell-mediated immunity, cytokine production, complement system, phagocytic function and secretory Ig A antibody concentrations (Woodward, 1998). For example, mice with protein calorie malnutrition infected with Mycobacterium tuberculosis express lower IFN- $\gamma$, tumor necrosis factor$\alpha$ and inducible NO in their lungs than do control mice. Malnourished mice also have higher numbers of bacilli in their lungs and higher mortality than do well-nourished mice (Macallan et al., 1999).

In the neonatal calf, the plane of nutrition during the first month of life specifically affects the somatotropic axis (Smith et al., 2002). In that study, increased nutrient intake sufficient to optimize growth performance was associated with elevated plasma IGF-1, insulin, glucose, and NEFA concentrations. Their data also demonstrated that in well-managed, MR-fed calves the somatotropic axis is functionally coordinated and sensitive to nutrient intake and growth hormone. Because the somatotropic axis influences developmental and functional aspects of the immune system (Kooijman et al., 1996; Clark, 1997), effects of an intensified feeding program may benefit the immune system of the neonatal calf. Conceivably, improved nutrition resulting from the feeding of an intensified MR would accelerate the maturation of the calf's immune system, promoting immune competency at an earlier age.

Based on results from controlled studies and in-house trials demonstrating the beneficial effects of intensified MR on growth rate and body composition, several companies are now marketing intensified MR (e.g., Advance Excelerate Calf Milk Replacer, Milk Specialties, Dundee, IL; Cow's Match, Land O'Lakes, Inc., Milk Products Co, Fort Dodge, IA; and Super Star 25-15, Merrick's, Inc., Middleton, WI). The immunological consequences of feeding intensified MR to neonatal calves, however, have not been investigated. The objective of this study was to compare the composition and functional capacities of PBMC populations from calves fed an intensified MR with PBMC populations from calves fed a diet meeting current industry standards.

\section{MATERIALS AND METHODS}

\section{Calves and Dietary Treatments}

Nineteen Holstein bull calves were acquired from four local dairy herds over a 2-wk period. At birth, navels were dipped in iodine and an Escherichia coli vaccine (Genecol-99, Shering Plough Animal Health, Union, NJ) was administered orally. All calves were given $3.9 \mathrm{~L}$ of pooled colostrum from the calf's source farm, via stomach tube. Within $24 \mathrm{~h}$ of birth, calves were moved to the greenhouse calf barn at the Cornell Teaching and Research Facility, Harford, NY, where they were housed individually in wire pens bedded with straw. Upon arrival at the Cornell farm, calves were examined physically, weighed and given $2 \mathrm{ml}$ of iron dextran $(100 \mathrm{mg} / \mathrm{ml}$, Butler, Columbus, OH) intramuscularly; $0.5 \mathrm{ml}$ of MuSe (11 mg of sodium selenite and $50 \mathrm{mg}$ of vitamin E/ml, Schering Plough Animal Health) intramuscularly, and $2 \mathrm{ml}$ of a vitamin B complex (Butler, Columbus, $\mathrm{OH}$ ) subcutaneously.

Prior to assignment to their respective treatment diets, calves were fed a MR (Milk Specialties Co.) consisting of $20 \% \mathrm{CP}$ and $20 \%$ fat reconstituted to $15 \%$ DM. They were fed twice daily, $0.3 \mathrm{~kg} /$ feeding. On the first Monday after they were born (average age: $4.2 \mathrm{~d}$ ), calves were assigned randomly to one of two treatment groups. Treatment (TRT) 1 calves $(n=9)$ were fed a $20 \%$ CP 20\% fat industry standard MR (Milk Specialties). In an attempt to simulate typical calf nutrition-management programs, TRT1 calves were offered $1.4 \%$ of BW in DM each day or $140 \%$ of the recommended feeding rate. This was considered necessary since calves were not offered starter and the trial occurred during the winter when cold stress can compromise growth and health. Treatment 2 calves $(\mathrm{n}=10)$ were fed a $30 \% \mathrm{CP}$ $20 \%$ fat MR (Milk Specialties) offered at $2.5 \%$ of BW in $\mathrm{DM}$ each day. Calves were fed MR reconstituted to $15 \%$ DM twice daily. The composition of both MR is shown in Table 1. Fresh water was offered with each feeding and was available at all times. Amounts of MR and water offered and refused were recorded at each feeding. Calves were weighed on 2 consecutive days of each week, and the average BW was used to determine the amount of MR offered the next week.

Calf health was monitored daily. Body temperatures were recorded daily for the first $2 \mathrm{wk}$, then only if calves were ill. Diarrhea was treated primarily with oral electrolytes (Entrolyte H. E., Pfizer Animal Health, Exton, 
Table 1. Composition of control diet (TRT1) and intensified diet (TRT2) milk replacers (MR). ${ }^{1}$

\begin{tabular}{lll}
\hline Constituent & TRT1 $\mathrm{MR}^{2}$ & TRT2 $\mathrm{MR}^{2}$ \\
\hline \%DM & 98.3 & 98.7 \\
\%CP & 19.6 & 29.5 \\
\%Fat & 20.1 & 20.5 \\
Calcium, \%DM & 1.1 & 1.1 \\
Phosphorus, \%DM & 0.82 & 0.76 \\
\hline
\end{tabular}

${ }^{1}$ Source of MR was Milk Specialties, Co., Dundee, IL.

${ }^{2}$ TRT1 MR was offered at $1.4 \%$ of BW in DM each day, whereas TRT2 MR was offered at $2.5 \% \mathrm{BW}$ in DM each day. The MR for both treatments was reconstituted to $15 \% \mathrm{DM}$.

PA), and MR was never withheld. Intravenous fluids were administered to severely dehydrated calves. Indices of health were monitored and recorded several times daily, under the following guidelines: Fecal scores: $1=$ firm, well-formed (not hard), 2 = soft, pudding-like, $3=$ runny, pancake batter, and $4=$ liquid, splatters; respiratory scores: $1=$ normal, $2=$ runny nose, $3=$ heavy breathing, $4=$ cough-moist, $5=$ cough-dry, and $6=$ fever. Other health disorders were diagnosed and treated according to veterinary instructions. All animal procedures were approved by the Institutional Animal Care and Use Committee of Cornell University.

\section{Blood Collection and PBMC Isolation}

Peripheral blood was collected biweekly from each calf, starting immediately before initiation of treatments and continuing until $60 \mathrm{~d}$ of age. Forty milliliters of blood, collected into $10 \%$ (vol/vol) $2 \times$ acid-citratedextrose [a sterilized solution containing sodium citrate $(77 \mu \mathrm{mol} / \mathrm{L})$, citric acid $(38 \mu \mathrm{mol} / \mathrm{L})$ and dextrose $(122$ $\mu \mathrm{mol} / \mathrm{L})]$, were taken from each side of the neck by jugular venipuncture. A smaller, anticoagulated (coagulant: potassium ethylenediaminetetraacetic acid) blood sample also was taken. Six pregnant, multiparous lactating cows housed at the Cornell Teaching and Research Farm were bled in a similar fashion on one occasion. Blood samples from calves and cows were shipped at ambient temperature by overnight delivery to the National Animal Disease Center (Ames, IA) for compositional and functional analyses of PBMC populations. Samples were collected the afternoon of the day before they were to be processed.

The PBMC used in assays evaluating cell function were isolated and enriched by density gradient centrifugation as described previously (Nonnecke et al., 1991). Contaminating erythrocytes were eliminated by hypotonic lysis prior to density gradient centrifugation of buffy coat cells. The PBMC-enriched populations were resuspended in RPMI-1640 medium (Gibco Laboratories, Grand Island, NY) that was supplemented with $2 \mathrm{mM}$ L-glutamine (Sigma, St Louis, MO), antibiotics, (100 U/ml of penicillin $\mathrm{G}$ and $100 \mathrm{mg} / \mathrm{ml}$ of streptomycin sulfate), and antimycotics $(0.25 \mathrm{mg} / \mathrm{ml}$ of amphotericin B; Gibco Laboratories). For the IFN- $\gamma$ assay, this medium was also supplemented with nonessential AA (Sigma Chemical Co.) and 2-mercaptoethanol (55 $\mu M$, Gibco Laboratories).

\section{Quantification of Serum Ig}

Concentrations of IgM and IgG in serum samples collected at birth and at $12 \mathrm{~h}$ of age were quantified by a modification of the ELISA used to determine Ig concentrations in supernatants from mitogen- and antigen-stimulated PBMC cultures (Nonnecke et al., 1992). Standards consisted of serially diluted, purified bovine IgG (reagent grade bovine IgG and IgM, Sigma). Mouse monoclonal antibody to bovine IgG and IgM antibody (Sigma) were used as detection antibodies. Secondary antibody consisted of biotinylated anti-mouse Ig from

Table 2. Primary and secondary antibodies used in the flow cytometric analysis of blood mononuclear cell populations from control and accelerated calves.

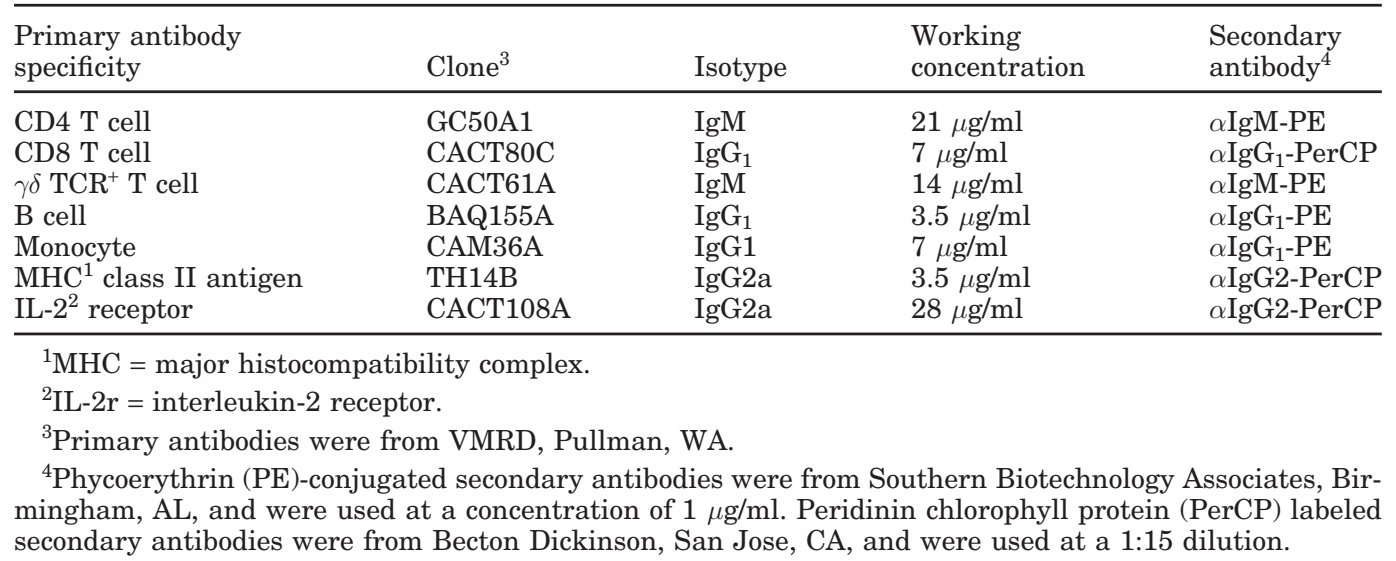


sheep (Amersham Life Sciences Inc., Arlington Heights, IL). Indicator consisted of streptavidin-biotinylated horseradish peroxidase complex with 2'azino-bis-3ethylbenzthiazoline sulfonic acid (National Veterinary Services Laboratory, Ames, IA) as the substrate. Pooled serum from adult dairy cows served as a positive control and heat-inactivated fetal bovine serum (FBS, Hyclone Laboratories, Inc., Logan, UT) served as a negative control.

\section{Analysis of PBMC Population Phenotype}

Leukocytes in PBMC populations were phenotyped by modifications of the flow cytometry procedure described previously (Nonnecke et al., 1993). A 15-ml aliquot of anticoagulated blood from each animal was centrifuged $(1000 \times g$, at room temperature for $20 \mathrm{~min})$. The buffy coat was harvested and contaminating erythrocytes were eliminated by hypotonic lysis. Cells were washed with and resuspended in PBS containing $0.02 \%$ $\mathrm{NaN}_{3}$ and $1 \%$ (vol/vol) heat-inactivated FBS (Hyclone Laboratories, Inc.). A 100- $\mu$ l aliquot, consisting of approximately $5 \times 10^{5}$ cells, was added to each of eight wells of a 96-well, round-bottom microtiter plate (Costar, Cambridge, MA) to determine phenotype. Individual wells had been preloaded with a $50-\mu$ l aliquot of monoclonal antibody (Table 2) diluted in PBS containing $0.02 \% \mathrm{NaN}_{3}$ and $1 \%$ inactivated FBS. Cells were incubated for $15 \mathrm{~min}$ at room temperature in the dark and the plate was centrifuged $(400 \times g$ for $2 \mathrm{~min}$ at room temperature). Supernatant was decanted and cells were resuspended in $100 \mu \mathrm{l}$ of each of two isotype specific antibodies conjugated to the listed fluorochromes (Table 1). These antibodies were diluted in PBS containing $0.02 \% \mathrm{NaN}_{3}$ and $1 \%$ inactivated FBS (Table 1). Incubation and centrifugation steps were repeated as described above. Cells were resuspended in $200 \mu \mathrm{l}$ of FacsLyse buffer (Becton Dickinson, San Jose, $\mathrm{CA}$ ) and stored in the dark at $4^{\circ} \mathrm{C}$ until examined on the flow cytometer.

Five thousand cells exhibiting light scattering properties consistent with bovine mononuclear leukocytes were analyzed. Markers were positioned for negative control samples to provide a background of $\sim 2 \%$ and were maintained at this position for all samples. Data were acquired using a FACScan flow cytometer (Becton Dickinson) and analyzed using CellQuest software (Becton Dickinson). Variables recorded for each marker were percentages of cells that stained positive. These data in combination with total numbers of circulating leukocytes were used to estimate the number of cells positive for each marker.

\section{In Vitro DNA Synthesis by PBMC}

The assay used to evaluate DNA synthesis by PBMC was performed as reported previously (Nonnecke, 1991). Briefly, cultures of PBMC were established in flat-bottomed, 96-well tissue culture plates (Costar) inoculated with $1.0 \times 10^{6} \mathrm{PBMC} / \mathrm{ml}$ in a total volume of $200 \mu \mathrm{l}$. All cultures contained 5\% (vol/vol) FBS (Hyclone Laboratories, Inc.). Synthesis of DNA by PBMC was assessed in unstimulated (i.e., resting) cultures and cultures stimulated with pokeweed mitogen (PWM, Sigma Chemical Co) at $2.0 \mu \mathrm{g} / \mathrm{ml}$ and concanavalin A (ConA) at $2.0 \mu \mathrm{g} / \mathrm{ml}$ of culture medium. Pokeweed mitogen is considered a T-dependent B cell mitogen (Franklin et al., 1994), whereas ConA is considered a $\mathrm{T}$ cell mitogen that specifically promotes responses by bovine regulatory (suppressor) T cells (Bielefeldt-Ohmann et al., 1983). Triplicate cultures were incubated for $66 \mathrm{~h}$ at $39^{\circ} \mathrm{C}$ in a humidified atmosphere of $5 \% \mathrm{CO}_{2}$. Cultures were pulsed at $48 \mathrm{~h}$ with $18.5 \mathrm{kBq}$ of [methyl- ${ }^{3} \mathrm{H}$ ]-thymidine (Amersham Corp., Arlington Heights, IL) in $50 \mu \mathrm{l}$ of RPMI-1640 medium. Cells were harvested onto glass fiber filters (model PHD cell harvester, Cambridge Technology, Watertown, MA) and retained radioactivity was measured by liquid scintillation spectrophotometry (LS8000 liquid scintillation counter, Beckman Instruments, Fullerton, CA). Synthesis of DNA by resting and mitogen stimulated cells was expressed as cpm.

\section{In Vitro Production and Measurement of IgM}

Secretion of polyclonal IgM by PBMC was evaluated in cell cultures established in flat-bottom, 96-well tissue culture plates. Individual wells were inoculated with 1 $\times 10^{6}$ cells $/ \mathrm{ml}$ in a total volume of $200 \mu \mathrm{l}$. All cultures contained 5\% (vol/vol) FBS (Hyclone Laboratories). Cultures were unstimulated (i.e., no mitogen) or stimulated with PWM (Sigma Chemical Co.) at $0.08 \mu \mathrm{g} / \mathrm{ml}$ or ConA at $0.08 \mu \mathrm{g} / \mathrm{ml}$ of culture medium. Triplicate cultures were incubated $8 \mathrm{~d}$ at $39^{\circ} \mathrm{C}$ in a humidified atmosphere of $5 \% \mathrm{CO}_{2}$. Culture supernatants from centrifuged plates $\left(800 \times g\right.$ at $4^{\circ} \mathrm{C}$ for $\left.2 \mathrm{~min}\right)$ were harvested and stored at $-80^{\circ} \mathrm{C}$ until analyzed. The concentration $(\mu \mathrm{g} /$ $\mathrm{ml}$ ) of IgM in supernatants from 14-d cultures was quantified by an ELISA as described previously (Nonnecke and Horst, 1992).

\section{In Vitro Production and Measurement of IFN- $\gamma$}

Secretion of IFN- $\gamma$ was evaluated in PBMC cultures established in flat-bottom, 96 -well tissue culture plates. Individual wells were inoculated with $4 \times 10^{6}$ cells $/ \mathrm{ml}$ in total volume of $200 \mu \mathrm{l}$. Cultures were unstimulated or stimulated with PWM ( $8 \mu \mathrm{g} / \mathrm{ml})$ or ConA $(8 \mu \mathrm{g} / \mathrm{ml})$ of culture medium with $5 \%$ (vol/vol) FBS, $55 \mu M$ of 2- 
mercaptoethanol, and nonessential AA. Cultures were incubated for $48 \mathrm{~h}$ at $39^{\circ} \mathrm{C}$ in a humidified atmosphere with $5 \% \mathrm{CO}_{2}$. Culture supernatants from centrifuged plates $\left(800 \times g\right.$ at $4^{\circ} \mathrm{C}$ for $\left.2 \mathrm{~min}\right)$ were harvested and stored at $-80^{\circ} \mathrm{C}$ until they could be analyzed. The concentration $(\mathrm{ng} / \mathrm{ml})$ of IFN- $\gamma$ in culture supernatants was quantified using an IFN- $\gamma$ capture ELISA as reported previously (Ametaj et al., 1996).

\section{In Vitro Production and Measurement of Inducible Nitric Oxide}

Production of inducible NO by PBMC was assayed in flat-bottom, 96-well tissue culture plates inoculated with $4 \times 10^{6}$ cells $/ \mathrm{ml}$ in a final volume of $200 \mu \mathrm{l}$. Cultures were unstimulated or stimulated with PWM $(8 \mu \mathrm{g} / \mathrm{ml})$ or ConA ( $8 \mu \mathrm{g} / \mathrm{ml}$ ) in RPMI 1640 medium with 5\% (vol/ vol) FBS. Duplicate cultures were incubated $48 \mathrm{~h}$ at $39^{\circ} \mathrm{C}$ in a humidified atmosphere with $5 \% \mathrm{CO}_{2}$. Nitrite is the stable oxidation product of $\mathrm{NO}$ produced in culture supernatants. For this reason, the amount of nitrite $(\mu M)$ in $100 \mu \mathrm{l}$ of culture supernatant was determined by a modification of the method of Green et al. (1982) as described previously (Rajaraman et al., 1998).

\section{Statistical Analysis}

Data were assessed for normality prior to statistical analysis. Arithmetic and $\log _{10}$-transformed data were analyzed as a split-plot with repeated measures ANOVA using Statview software (version 5.0, SAS Institute, Inc., Cary, NC). The model included effects of treatment (i.e., control vs. intensified diets), time (days on trial), and the interaction of treatment and time on growth, health variables, number of circulating leukocytes, composition of PBMC populations, and functional capacities of PBMC populations in vitro. Fisher's protected-LSD test was applied when significant effects $(P$ $<0.05)$ were detected by the model.

\section{RESULTS}

\section{Effect of Intensified Diet on Growth and Health}

Effects of standard and intensified diets on growth performance of calves are shown in Figure 1. Mean BW of calves in TRT1 (standard diet, $\mathrm{n}=9$ ) and TRT2 (intensified diet, $\mathrm{n}=10$ ) groups were not different at birth or at $4 \mathrm{~d}$ of age. From 11 to $60 \mathrm{~d}$ of age, the mean BW of TRT2 calves was consistently greater $(P<0.05)$ than TRT1 calves. During this period, the mean daily BW gain of TRT2 calves was more than twice the BW gain of TRT1 calves ( $1.20 \mathrm{vs.} 0.55 \mathrm{~kg} / \mathrm{d})$. By $60 \mathrm{~d}$ of age, the mean BW of TRT2 calves was $53 \%$ greater $(P<$ $0.0001)$ than that of TRT1 calves (112.9 vs. $73.7 \mathrm{~kg})$.
The composition of growth caused by feeding intensified MR has been described previously (Diaz et al., 2001).

Measurement of Ig concentrations in the circulation of young calves provides an indication of degree of passive immunity acquired through ingestion of colostrum. Serum IgG and IgM concentrations were determined for TRT1 $(n=8)$ and TRT2 $(n=7)$ calves at birth and at $12 \mathrm{~h}$ of age. The mean IgG concentration was substantially higher at $12 \mathrm{~h}$ of age than at birth (14.3 vs. $0.08 \mathrm{~g} / \mathrm{L} ; P<0.0001 ; \mathrm{n}=15)$. The concentration of serum IgM also was higher at $12 \mathrm{~h}$ of age than at birth (4.81 vs. $0.15 \mathrm{~g} / \mathrm{L} ; P<0.0001 ; \mathrm{n}=15$ ). Group (i.e., TRT1 and TRT2) differences in Ig concentrations were not significant at birth (IgG: $P=0.80$; IgM: $P=0.07$ ) or at 12 h of age (IgG: $P=0.41$; IgM: $P=0.86$ ). These data clearly indicate that the calves received adequate colostrum to assure Ig-dependent passive immunity had been achieved.

A variety of subjective measurements of health was recorded on a weekly basis during the experimental period. These included respiratory and fecal scores (data not shown). Treatment 2 calves, when compared to TRT1 calves, had higher overall mean respiratory scores (1.55 vs. 1.10) as well as fecal scores (2.03 vs. 1.42). In general, calves assigned to TRT2 exhibited softer feces compared with calves on TRT1, reflecting the difference in the total volume of feed and water consumed. Overall, the health of TRT 1 and 2 calves was comparable during the trial.

\section{Effect of Intensified Diet on Composition of PBMC Population}

Effects of diet, time, and their interaction on the composition of PBMC populations from MR-fed calves are summarized in Table 3. Blood samples were taken biweekly, beginning at $4 \mathrm{~d}$ of age and concluding at $60 \mathrm{~d}$ of age. The ANOVA indicated that the total number of circulating leukocytes was unaffected by treatment $(P$ $=0.96)$ or time $(P=0.36)$. The treatment $\times$ day interaction was not significant $(P=0.61)$. Mean numbers of circulating leukocytes ranged from $11.4( \pm 0.7) \times 10^{6} / \mathrm{ml}$ at $4 \mathrm{~d}$ of age to $10.2( \pm 0.7) \times 10^{6} / \mathrm{ml}$ at $60 \mathrm{~d}$ of age.

Diet did not affect percentages of $\gamma \delta \mathrm{T}$ cell receptor ${ }^{+}$ $(P=0.66), \mathrm{CD}^{+}(P=0.93)$ and $\mathrm{CD}^{+}(P=0.28) \mathrm{T}$ cells; B cells $(P=0.96)$, and monocytes $(P=0.06)$ or the expression of activation markers, i.e., major histocompatibility complex (MHC) class II antigen $(P=0.68)$ and interleukin-2 receptor (IL-2r; $P=0.68)]$. Treatment and time interactions for these variables also were insignificant $(P>0.05)$.

Biweekly changes in the composition of PBMC populations from TRT1 (control diet) and TRT2 (high plane of nutrition) calves are shown in Figures 2 (i.e., percent 
Table 3. Results ( $P$ values) of repeated-measures ANOVA for phenotype variables describing peripheral blood mononuclear cell (PBMC) populations ${ }^{1}$ from preruminant calves 4 to $60 \mathrm{~d}$ of age.

\begin{tabular}{llll}
\hline Variable & Treatment effect & Time effect & Interaction \\
\hline $\begin{array}{l}\text { Total \# of leukocytes } \\
\text { Contribution to PBMC population, \%: }\end{array}$ & NS $^{2}(0.96)$ & NS $(0.36)$ & NS $(0.71)$ \\
$\gamma \delta$-TCR ${ }^{+3}$ cells & NS $(0.66)$ & $<0.0001$ & NS $(0.52)$ \\
CD4 $^{+}$cells & NS $(0.93)$ & $<0.0001$ & NS $(0.98)$ \\
CD8 cells & NS $(0.28)$ & $<0.0001$ & NS $(0.96)$ \\
CD4:CD8 ratio & NS $(0.20)$ & $<0.0001$ & NS $(0.72)$ \\
B cells & NS $(0.34)$ & $<0.001$ & NS $(0.96)$ \\
Monocytes & NS $(0.06)$ & NS $(0.22)$ & NS $(0.59)$ \\
MHC $^{4}$ class II ${ }^{+}$cells & NS $(0.68)$ & $<0.0001$ & NS $(0.99)$ \\
IL-2r $^{+, 5}$ cells & NS $(0.51)$ & $<0.0001$ & NS $(0.62)$ \\
\hline
\end{tabular}

${ }^{1}$ Total number of leukocytes determined by electronic cell counting and cell phenotype by flow cytometry.

${ }^{2} \mathrm{NS}=$ Not significant, $P>0.05$.

${ }^{3} \gamma \delta \mathrm{TCR}=\gamma \delta \mathrm{T}$ cell receptor.

${ }^{4} \mathrm{MHC}=$ Major histocompatibility complex.

${ }^{5} \mathrm{IL}-2 \mathrm{r}=$ Interleukin-2 receptor.

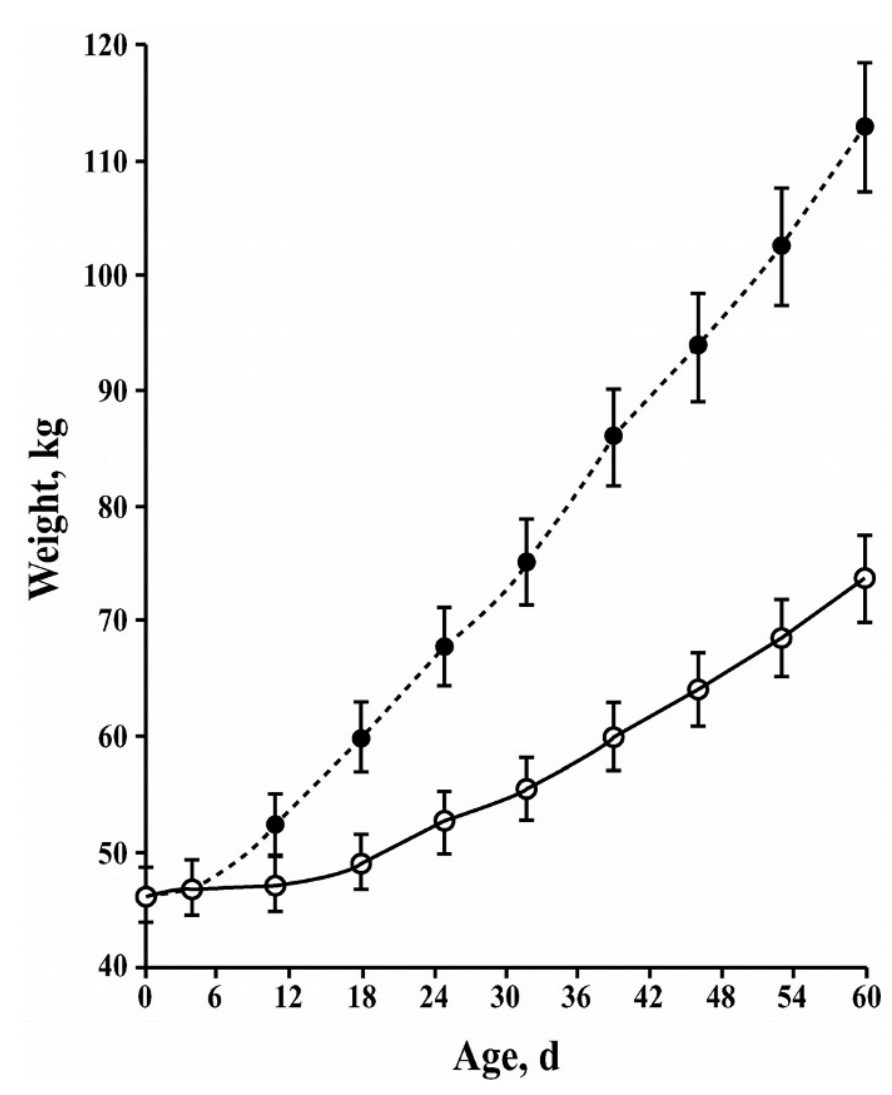

Figure 1. Effect of the plane of nutrition on the growth performance of milk replacer-fed calves. Mean $( \pm$ SEM) BW of calves fed standard and intensified milk replacers from 0 to $60-\mathrm{d}$ of age are shown. Control calves (-O-) were fed a $20 \% \mathrm{CP}, 20 \%$ fat industry standard milk replacer offered at $1.4 \%$ of BW in DM each day. High plane of nutrition calves (-0-) were fed a $30 \%$ CP $20 \%$ fat milk replacer offered at $3.0 \%$ of BW in DM each day. Milk replacers were reconstituted to $15 \% \mathrm{DM}$.
$\mathrm{T}$ and $\mathrm{B}$ cells) and 3 (i.e., percent $\mathrm{MHC}$ class $\mathrm{II}^{+}$and IL2-r $\mathrm{r}^{+}$. Although the composition of PBMC population was unaffected by the plane of nutrition, responses of both TRT1 and 2 calves are shown to indicate the similarity of their PBMC populations throughout the experimental period.

Longitudinal changes in the composition of PBMC populations were observed in all calves. The mean percentage of $\gamma \delta \mathrm{TCR}^{+} \mathrm{T}$ cells decreased $(P<0.0001)$ with age, from $42.4 \%$ at $4 \mathrm{~d}$ of age to $20.6 \%$ and $27.5 \%$ at 46 and $56 \mathrm{~d}$ of age. The $\mathrm{CD} 4^{+}$cell percentage on $\mathrm{d} 4(14.6 \%)$, $46(15.8 \%)$, and $60(14.3 \%)$ were not different $(P>0.05)$; however, on $\mathrm{d} 18(27.2 \%)$ and $32(28.2 \%)$ they were higher than on $\mathrm{d} 4,46$, and $60(P<0.0001)$. The percentage of $\mathrm{CD}^{+}$cells was lower on d $18(8.5 \% ; P=0.02)$ and $46(8.1 \% ; P=0.02)$, and higher on d $60(27.5 \%, P$ $=0.01)$ than at the beginning of the study $(\mathrm{d} 4,17.5 \%)$. B cell percentage increased $(P<0.0001)$ with age and on d $46(13.4 \%)$ and $60(14 \%)$ was higher $(P<0.01)$ than on $\mathrm{d} 4(8.4 \%)$. Reflecting these changes was the dramatic increase $(P<0.0001)$ in the CD4:CD8 T cell ratio from $0.85( \pm 0.09)$ on $d 4$ to $4.59( \pm 0.47)$ on $d 18$ and $3.56(+0.36)$ on $d 32$. The ratio subsequently decreased and by d $60(1.0 \pm 0.20)$ was comparable to the ratio on $d 4$.

Monocyte percentages remained unchanged $(P>$ 0.05 ) during the period, ranging from $20.8 \%$ on $d 4$ to $17.4 \%$ on d 60 (data not shown).

Although MHC class II antigen and IL-2r are expressed constitutively on cells within the PBMC population, their increased expression is indicative of cell activation. The percentage of MHC class II antigen-positive cells was higher $(P<0.0001)$ on d $18(55.1 \%), 32(57.7 \%)$, $46(49.5 \%)$, and $60(39.2 \%)$ than on $\mathrm{d} 4(22.7 \%)$. Interleukin-2 receptor expression was higher on d 18 (36.8\%; 

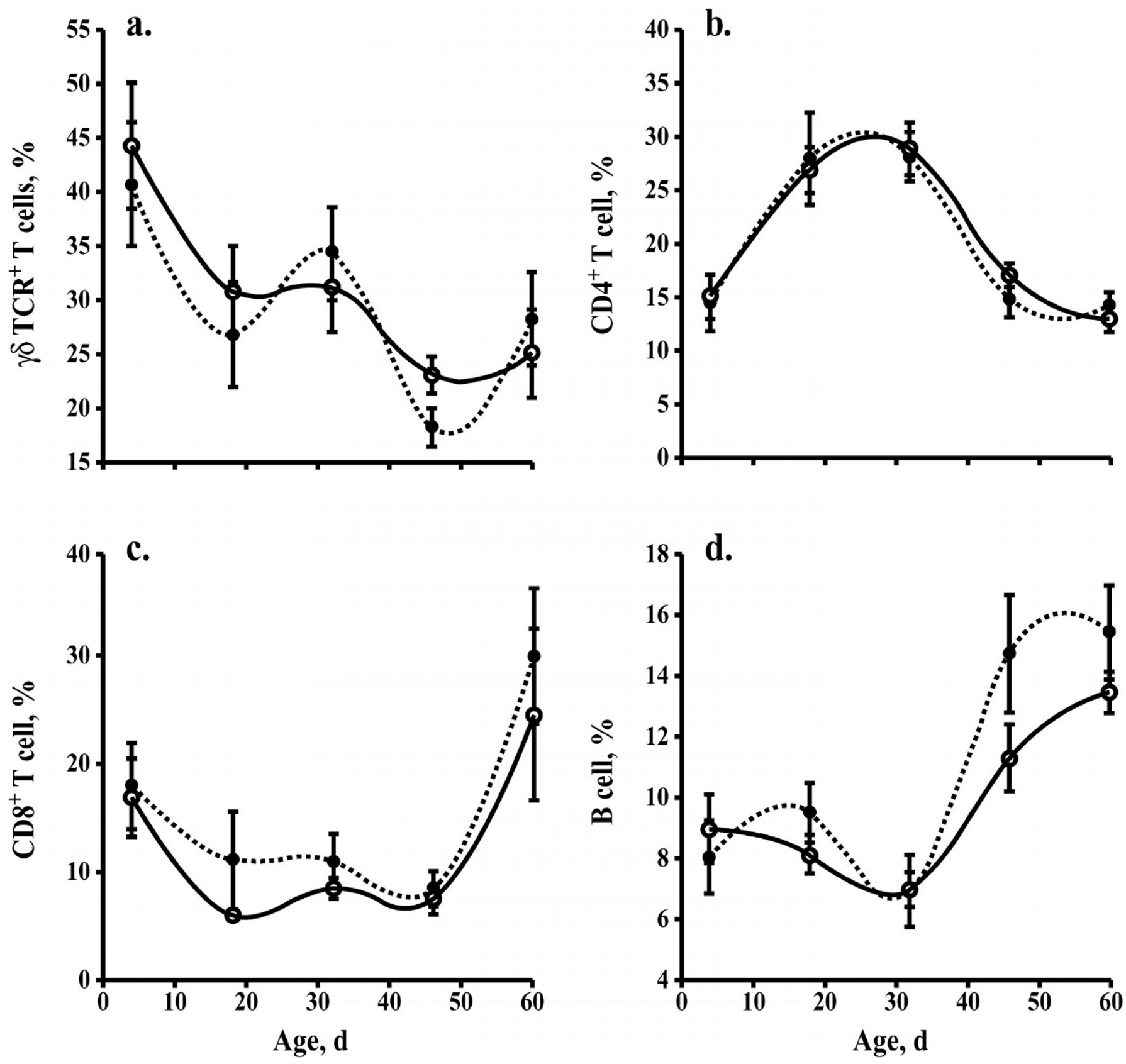

Figure 2. Effect of the plane of nutrition on T cell populations in peripheral blood from milk replacer-fed calves. Mean ( \pm SEM) percentages of $\gamma \delta \mathrm{T}$ cell receptor $(\mathrm{TCR})^{+}(\mathrm{a}), \mathrm{CD}^{+}$(b), $\mathrm{CD}^{+}$(c) T cells and B cells (d) in peripheral blood mononuclear cell (PBMC) populations from control (-O-) and high plane of nutrition (-๑-) calves are shown.

$P<0.01)$ and $32(43.9 \% ; P<0.0001)$ and lower on $\mathrm{d} 60$ $(11.8 \%, P<0.05)$ when compared to expression on $\mathrm{d}$ $4(22.5 \%)$.

\section{Effect of Intensified Diet on PBMC Function}

Effects of diet, time, and their interaction on ex vivo functional capacities of PBMC from MR-fed calves are summarized in Table 4. The ANOVA revealed that diet had no effect $(P>0.05)$ on mitogen-induced lymphocyte blastogenesis or IgM secretion. Longitudinal changes (i.e., time effect) in the activities of cells in these specific assays, however, were significant $(P<0.0001)$. Responses of both TRT1 and TRT2 calves are shown in Figures 4 and 5 to indicate the functional similarity of these populations during the experimental period. 

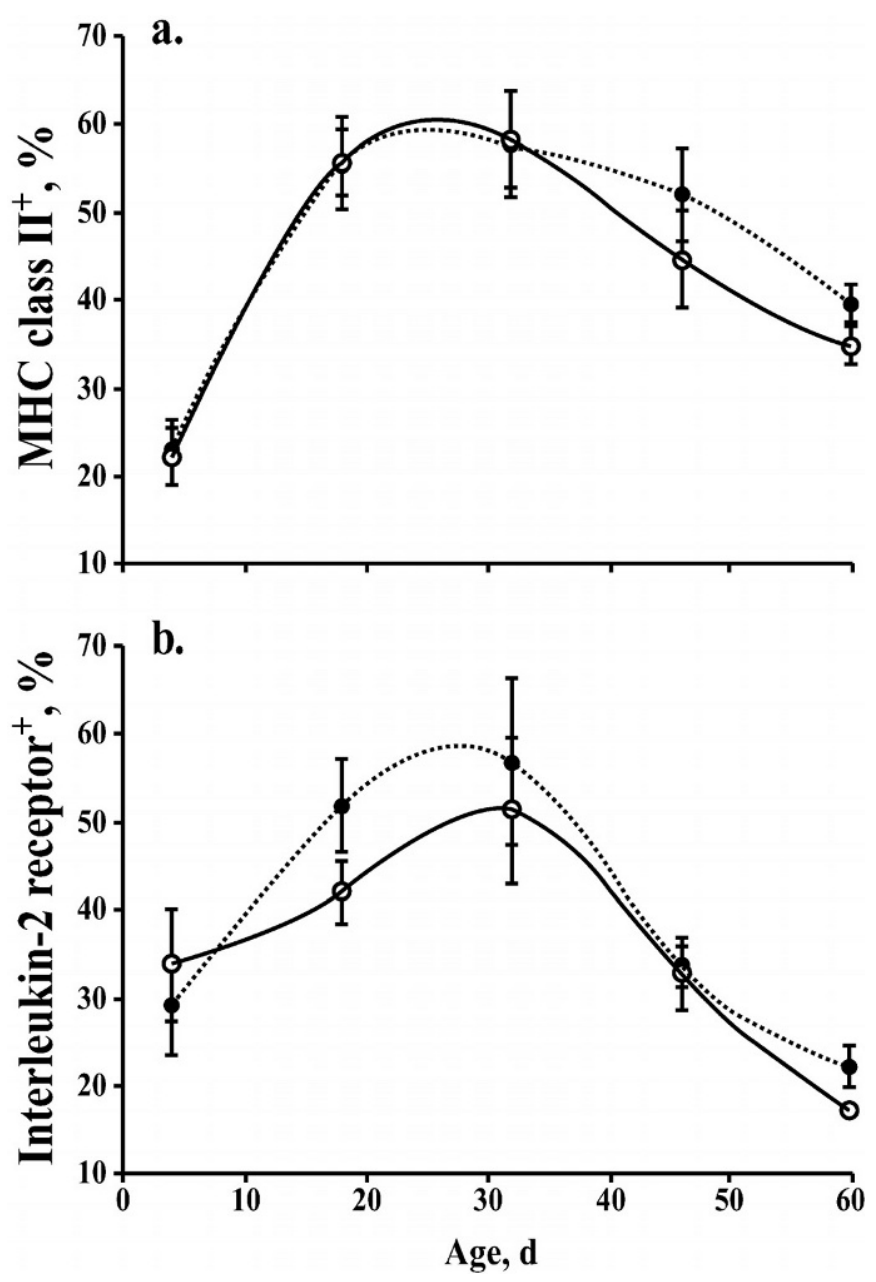

Figure 3. Effect of the plane of nutrition on expression of activation markers by peripheral blood mononuclear cells (PBMC) from milk replacer-fed calves. Mean ( \pm SEM) percentages of major histocompatibility class $\mathrm{II}^{+}$(a) and interleukin-2 receptor (IL-2r) ${ }^{+}$(b) cells in peripheral blood mononuclear cell (PBMC) populations from control (-O-) and high plane of nutrition (-) calves are shown.

Longitudinal changes in lymphocyte blastogenesis and IgM secretion were observed in all calves. Pokeweed mitogen-induced blastogenic responses were lowest at 4 $\mathrm{d}$ of age $\left(6 \times 10^{3} \mathrm{cpm}\right)$, increased $(P<0.0001)$ markedly by $18 \mathrm{~d}$ of age $\left[22 \times 10^{3} \mathrm{cpm}\right.$ (Figure $\left.4 \mathrm{a}\right)$ and remained elevated for the duration of the study. On $d 60$ the mean response was $18 \times 10^{3} \mathrm{CPM} / \mathrm{min}$. Longitudinal changes in ConA-induced blastogenesis followed a similar pattern (Figure $4 \mathrm{~b}$ ). It is important to note that maximal PWM- and ConA-induced responses of calf PBMC during the period were substantially lower than responses of adult PBMC cultured under identical conditions.

Pokeweed-induced secretion of IgM on d $4(1.41 \mu \mathrm{g} /$ $\mathrm{ml}), 18(1.77 \mu \mathrm{g} / \mathrm{ml}), 32(1.50 \mu \mathrm{g} / \mathrm{ml})$, and $46(1.77 \mu \mathrm{g} /$ $\mathrm{ml}$ ) was comparable (Figure 5a). Although PWM-induced IgM secretion $(2.37 \mu \mathrm{g} / \mathrm{ml})$ by calf cells was maximal ( $P$
$<0.01$ ) on $\mathrm{d} 60$, it was substantially less than mean IgM secretion $(14.3 \mu \mathrm{g} / \mathrm{ml})$ by adult PBMC cultured under identical conditions. Longitudinal changes in ConA-induced IgM secretion followed a different pattern with maximal secretion occurring on d $4(1.43 \mu \mathrm{g} / \mathrm{ml})$. Secretion decreased $(P<0.0001)$ progressively from $\mathrm{d} 4$ through d 60, and on d 60 averaged $1.18 \mu \mathrm{g} / \mathrm{ml}$. Adult PBMC cultured under identical conditions produced substantially more IgM $(2.1 \mu \mathrm{g} / \mathrm{ml})$.

Secretion of IFN- $\gamma$ and NO, both essential for effective cell-mediated immunity were influenced by diet (Table 4). Pokeweed mitogen-induced IFN- $\gamma$ responses of TRT1 calves increased progressively from d $4(0.18 \mathrm{ng} / \mathrm{ml})$ through d $60(1.09 \mathrm{ng} / \mathrm{ml})$ (Figure 6a). In contrast, responses of TRT2 calves were characterized by an early, rapid increase $(P<0.05)$ in IFN- $\gamma$ secretion that was maximal on d 18 and $32(1.16$ and $1.14 \mathrm{ng} / \mathrm{ml}$, respectively vs. $0.48 \mathrm{ng} / \mathrm{ml}$ on d 4 ). On d 18, responses of TRT2 calves exceeded responses of TRT 1 calves ( 1.16 vs. 0.54 $\mathrm{ng} / \mathrm{ml} ; P<0.05)$. From d 32 through d 60 , responses of TRT2 calves decreased progressively and on d 60 were lower than responses of TRT1 calves $(0.48 \mathrm{vs} .1 .1 \mathrm{ng} / \mathrm{ml}$, $P<0.05$ ).

Concanavalin A-induced IFN- $\gamma$ responses of TRT1 and TRT2 calves are shown in Figure 6b. Responses of PBMC from both groups were comparable from d 4 through 32 , however, responses of TRT1 calves increased progressively from d 32 to 60 . By d 60, PBMC from TRT1 calves produced more IFN- $\gamma$ than PBMC from TRT2 calves ( 0.13 vs. $0.05 \mathrm{ng} / \mathrm{ml}, P<0.05$ ). Maximal PWM- and ConAinduced IFN- $\gamma$ responses of calf PBMC during the experimental period were less than IFN- $\gamma$ responses of adult PBMC cultured under the same conditions (Figure 6).

Nitric oxide secretion by mitogen-stimulated PBMC from TRT1 and 2 calves is shown in Figure 7. At $4 \mathrm{~d}$ of age, responses of TRT1 and 2 calves to mitogenic stimulation were comparable and substantially less than responses of adult PBMC. In general, mitogen-induced NO production by PBMC from all calves increased $(P<$ $0.0001)$ progressively with age. At $18 \mathrm{~d}$ of age, NO responses of all calves (PWM stimulated: $40.3 \pm 4.4 \mu M$; ConA stimulated: $51.1 \pm 5.0 \mu M ; \mathrm{n}=19)$ were comparable to responses of adults (PWM stimulated: $33.8 \pm 1.6 \mu M$; ConA stimulated: $41.9 \pm 3.5 \mu M ; \mathrm{n}=6$ ). On $\mathrm{d} 60$, the PWM-induced NO response of TRT2 calves $(62.9 \mu M)$ exceeded responses of TRT1 calves $(39.2 \mu M ; P<0.05)$ and adults $(33.8 \mu M ; P<0.05)$ (Figure 7a). Concanavalin A-induced responses of TRT2 calves exceeded responses of TRT1 calves on d 46 and $60(P<0.05)$ and adult responses on d $60(P<0.05)$ (Figure $7 \mathrm{~b})$.

\section{DISCUSSION}

Calf MR are now available commercially that provide a level of nutrition that mimics the protein and energy 
Table 4. Results ( $P$ values) of repeated-measures ANOVA for variables describing functions of peripheral blood mononuclear cell (PBMC) populations from preruminant calves 4 to $60 \mathrm{~d}$ of age.

\begin{tabular}{llll}
\hline Variable & Treatment effect & Time effect & Interaction \\
\hline Lymphocyte blastogenesis & & & \\
Not stimulated & $\mathrm{NS}^{3}(0.88)$ & $<0.0001$ & $<0.05$ \\
$\mathrm{PWM}^{1}$ stimulated & $\mathrm{NS}(0.66)$ & $<0.0001$ & $\mathrm{NS}(0.29)$ \\
$\mathrm{ConA}^{2}$ stimulated & $\mathrm{NS}(0.96)$ & $<0.0001$ & $\mathrm{NS}(0.30)$ \\
Polyclonal IgM secretion & $\mathrm{NS}(0.14)$ & $<0.0001$ & $\mathrm{NS}(0.68)$ \\
Not stimulated & $\mathrm{NS}(0.63)$ & $<0.0001$ & $\mathrm{NS}(0.34)$ \\
PWM stimulated & $\mathrm{NS}(0.67)$ & $<0.0001$ & $\mathrm{NS}(0.69)$ \\
ConA stimulated & $\mathrm{NS}(0.09)$ & $\mathrm{NS}(0.63)$ & $\mathrm{NS}(0.29)$ \\
Interferon- $\gamma$ secretion & $\mathrm{NS}(0.57)$ & $<0.01$ & $<0.01$ \\
Not stimulated & $\mathrm{NS}(0.10)$ & $<0.0001$ & $<0.05$ \\
PWM stimulated & $\mathrm{NS}(0.16)$ & $\mathrm{NS}(0.08)$ & $\mathrm{NS}(0.37)$ \\
ConA stimulated & $<0.05$ & $<0.0001$ & $<0.05$ \\
Inducible nitric oxide secretion & $<0.05$ & $<0.0001$ & $<0.05$ \\
Not stimulated & & & \\
PWM stimulated & & & \\
ConA stimulated & & &
\end{tabular}

content of cow's milk. The benefits of these intensified diets on growth rate and body composition have been established (Diaz et al., 2001; Smith et al., 2002). Effects of intensified diets on the calf's immune system, however, have not been elucidated. Conceivably, the beneficial effects of an intensified diet would also extend to the immune system. Immunological consequences of a higher plane of nutrition might be manifested by accelerated maturation (i.e., calf $\mathrm{PBMC}$ populations that are functionally and compositionally more like that of adult cattle) of the calf's immune system.

In the present study, the average growth rate $(1.20$ $\mathrm{kg} / \mathrm{d}$ ) of calves fed an intensified diet was substantially higher than the growth rate $(0.55 \mathrm{~kg} / \mathrm{d})$ of calves fed a traditional diet from 11 to $60 \mathrm{~d}$ of age. These results are comparable to those of previous studies evaluating effects of nutrient intake on growth performance of Holstein bull calves (Diaz et al., 2001; Smith et al., 2002). The number of circulating leukocytes and the composition of PBMC populations, however, was unaffected by diet. Percentages of $\mathrm{T}\left(\gamma \delta \mathrm{TCR}^{+}, \mathrm{CD}^{+}\right.$, and $\left.\mathrm{CD} 8^{+}\right)$cells in the circulation of calves fed standard and intensified diets were similar throughout the experimental period. Percentages of B cells and cells expressing MHC class II (i.e., monocytes and B cells) and IL-2r (i.e., T cells) also were unaffected by the plane of nutrition. Previous research indicates that protein-energy nutrition can affect the composition of blood leukocyte populations. In chronic protein-energy malnutrition, the proportion of $\mathrm{T}$ helper-inducer $\left(\mathrm{CD}^{+}\right)$lymphocytes is markedly decreased, whereas the proportion of cytotoxic-suppressor $\left(\mathrm{CD}^{+}\right)$lymphocytes is only moderately decreased, resulting in lower $\mathrm{CD}^{+}$: $\mathrm{CD}^{+} \mathrm{T}$ cell ratio (Chandra, 1982).
If calves fed the standard diet were moderately to severely undernourished (i.e., protein and energy content of the diet were not sufficient to meet the requirements of the immune system), then differences in proportions of $\mathrm{T}$ cells might have been evident. The absence of differences between PBMC populations from control and intensified calves indicate that the industry standard diet provided sufficient nutrition to maintain the composition of the neonate's PBMC population.

A more detailed examination of the phenotypes of circulating CD4 and CD8 cells might have revealed subtle effects of nutrition not detected in the current study. This possibility is suggested by research in rodents indicating that there is an overabundance of $\mathrm{CD}^{+} \mathrm{CD} 45 \mathrm{RA}^{+}$and $\mathrm{CD}^{+} \mathrm{CD} 45 \mathrm{RA}^{+} \mathrm{CD} 62 \mathrm{~L}^{+}$(both representing naive versus memory/effector $\mathrm{T}$ cell phenotypes) in the blood and lymphoid tissues during protein and energy deficiencies (Woodward et al., 1999; ten Bruggencate et al., 2001). This imbalance within $\mathrm{T}$ cell subsets would favor immunological quiescence, reduced cytokine production, and lowered immunocompetency. The effects of neonatal nutrition on memory $\mathrm{T}$ cells in neonatal calves needs further investigation.

Longitudinal changes in proportions of $\gamma \delta \mathrm{TCR}^{+} \mathrm{T}$ cells and $\mathrm{B}$ cells observed in all calves are indicative of maturational changes in the neonatal bovine immune system. The $\gamma \delta \mathrm{TCR}^{+}$cell subset was the predominant lymphocyte population (i.e., exceeded proportions of CD4 and CD8 T cells as well as B cells) at $4 \mathrm{~d}$ of age, a characteristic of PBMC populations in young ruminants (Hein and Mackay, 1991; Wyatt et al., 1994). The subsequent decline in this $\mathrm{T}$ cell subset with increasing age is typical of young ruminants, including MR-fed dairy calves (Hein 

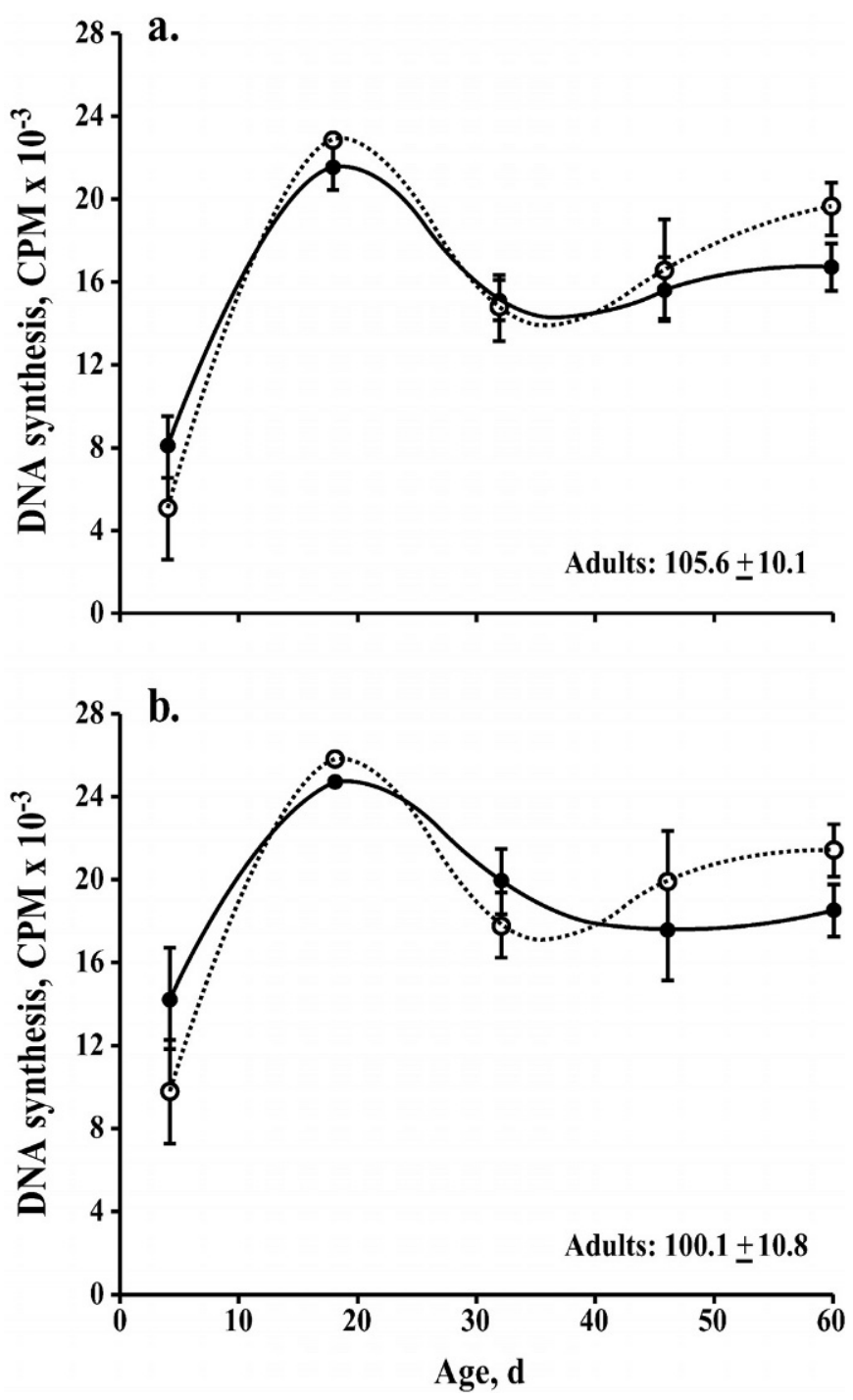

Figure 4. In vitro effect of the plane of nutrition mitogen-induced $\left[{ }^{3} \mathrm{H}\right]$-thymidine incorporation [cpm] by peripheral blood mononuclear cells (PBMC) from milk replacer-fed calves. Mean ( \pm SEM) responses of PBMC from control (-O-) and high plane of nutrition calves (-0-) to pokeweed mitogen (a) and concanavalin A (b) are shown. Corresponding responses of adults (mean \pm SEM, $\mathrm{n}=6$ ) PBMC are shown in the lower right hand corner of each panel.

and Mackay, 1991; Wyatt et al., 1994; Nonnecke et al., 1999). The percentage of B cells increased with time, most notably from 32 to $60 \mathrm{~d}$ of age. Similar age-dependent increases in the proportion of circulating B cells in young calves have been reported (Senogles et al., 1978; Menge, et al., 1999; Nonnecke et al., 1999) and also is typical of the maturing immune system of the calf. The transient, early increase in percentages of $\mathrm{CD} 4^{+} \mathrm{T}$ cells and cells expressing activation antigens (i.e., MHC class II antigen and IL-2r expression increased on stimulated lymphocytes and monocytes) may be indicative of a state
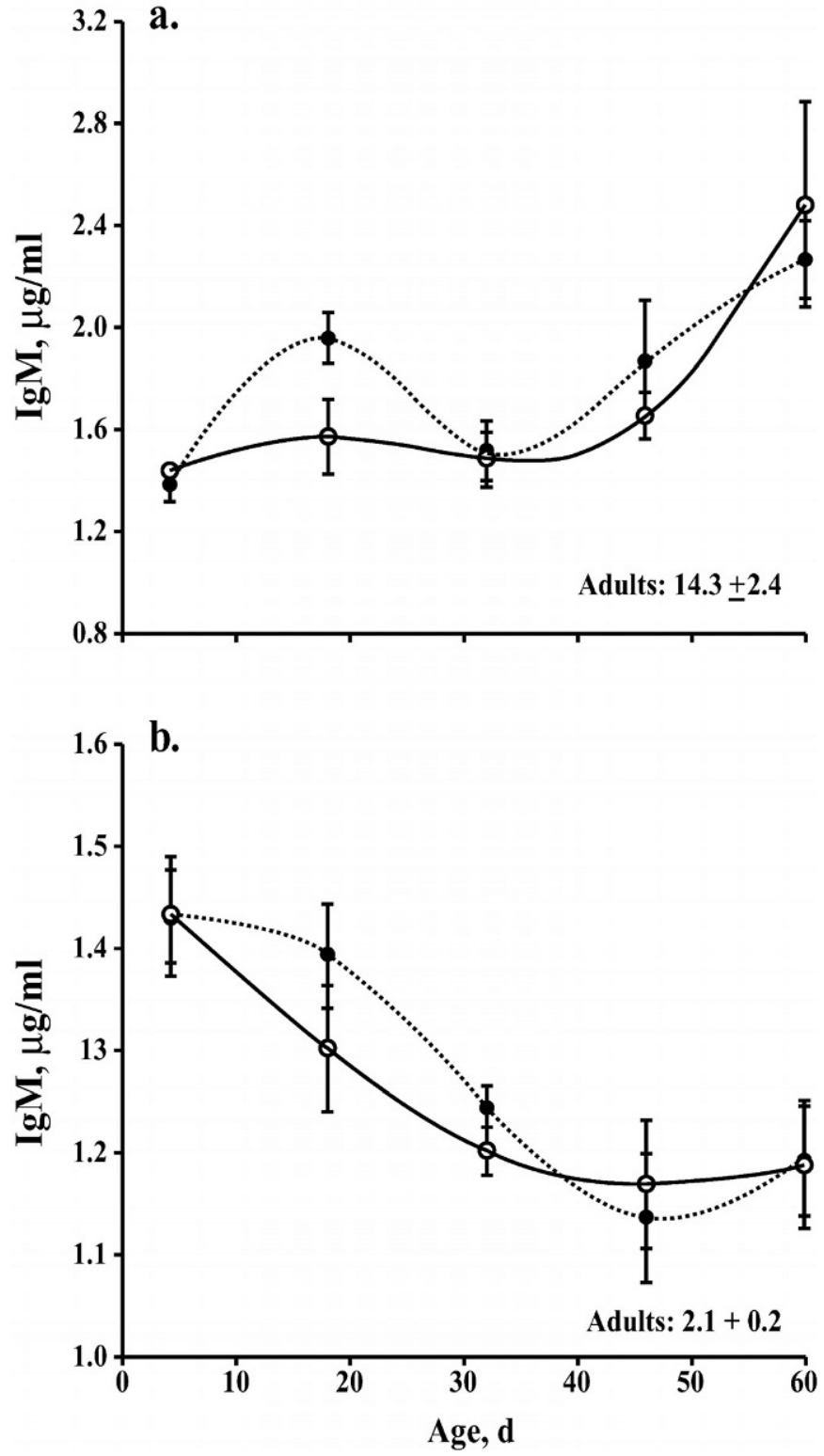

Figure 5. In vitro effect of the plane of nutrition mitogen-induced Ig M synthesis by peripheral blood mononuclear cells (PBMC) from milk replacer-fed calves. Mean ( \pm SEM) responses of PBMC from control (-O-) and high plane of nutrition calves (-๑) to pokeweed mitogen (a) and concanavalin A (b) are shown. Corresponding responses of adults (mean \pm SEM, $\mathrm{n}=6$ ) PBMC are shown in the lower right hand corner of each panel.

of immune activation. Conceivably, the calf's natural exposure and adaptation to the range of microbes present in its environment contributed to these changes in the PBMC population. Overall, these data suggest that the increased dietary energy and protein provided by the intensified diet did not modulate (i.e., promote) maturation-related changes in the composition of calf PBMC populations. 

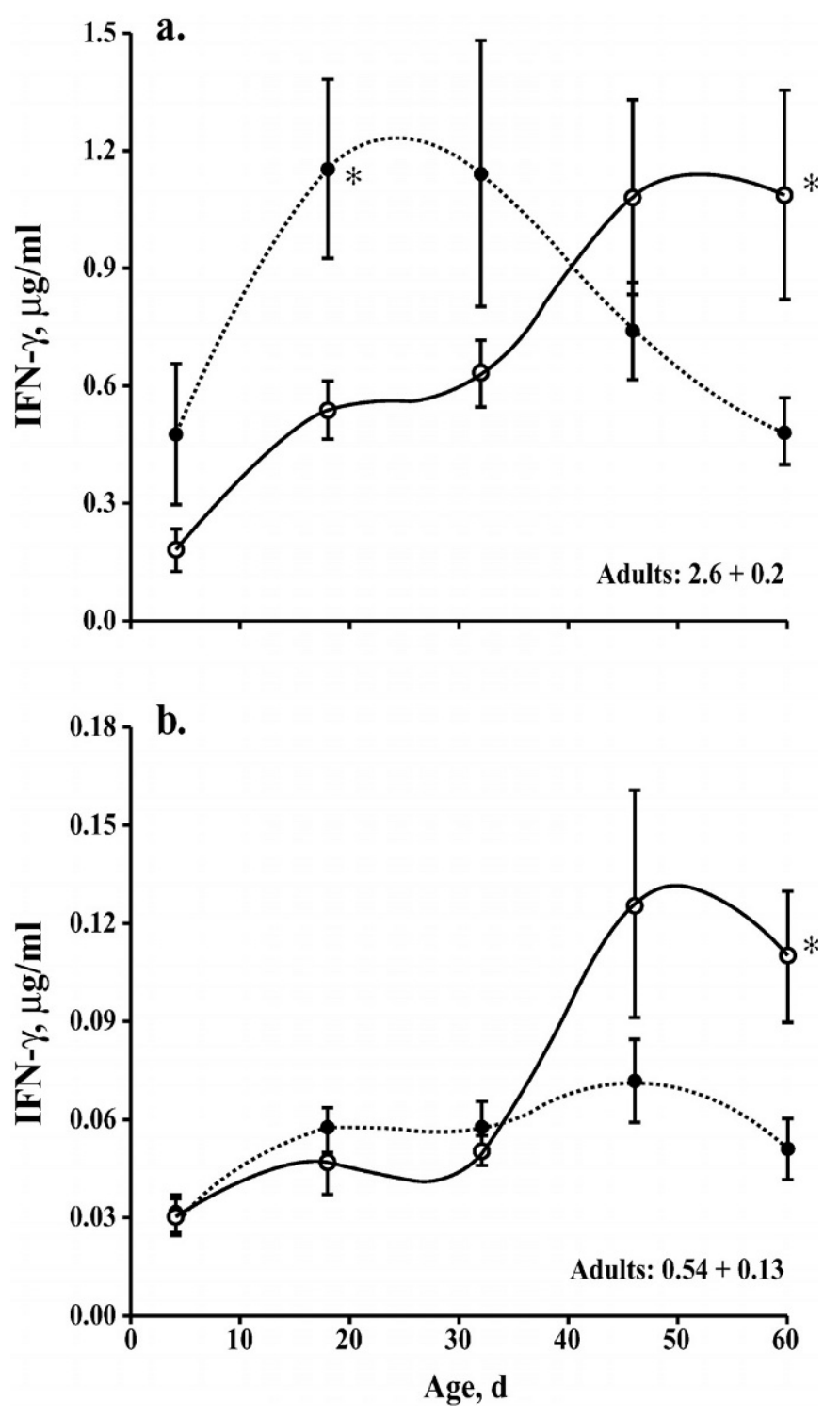

Figure 6. In vitro effects of the plane of nutrition mitogen-induced interferon gamma (IFN- $\gamma$ ) synthesis by peripheral blood mononuclear cells (PBMC) from milk replacer-fed calves. Mean ( \pm SEM) responses of PBMC from control (-O-) and high plane of nutrition calves (-0-) to pokeweed mitogen (a) and concanavalin A (b) are shown. Asterisk indicates control and treatment means differed $(P<0.05)$ on that specific day. Corresponding responses of adults (mean \pm SEM, $\mathrm{n}=6$ ) $\mathrm{PBMC}$ are shown in the lower right hand corner of each panel.

Time and resources frequently limit the number and types of assays that can be performed in studies evaluating effects of a specific treatment on immune function. In the present study, effects of intensified nutrition on functional capacity of calf and adult PBMC populations was evaluated using four assays. The general responsiveness of PBMC was quantified using a DNA-synthesis assay, whereas specific aspects of T-dependent B cell function, $\mathrm{T}$ and natural killer cell function, and monocyte
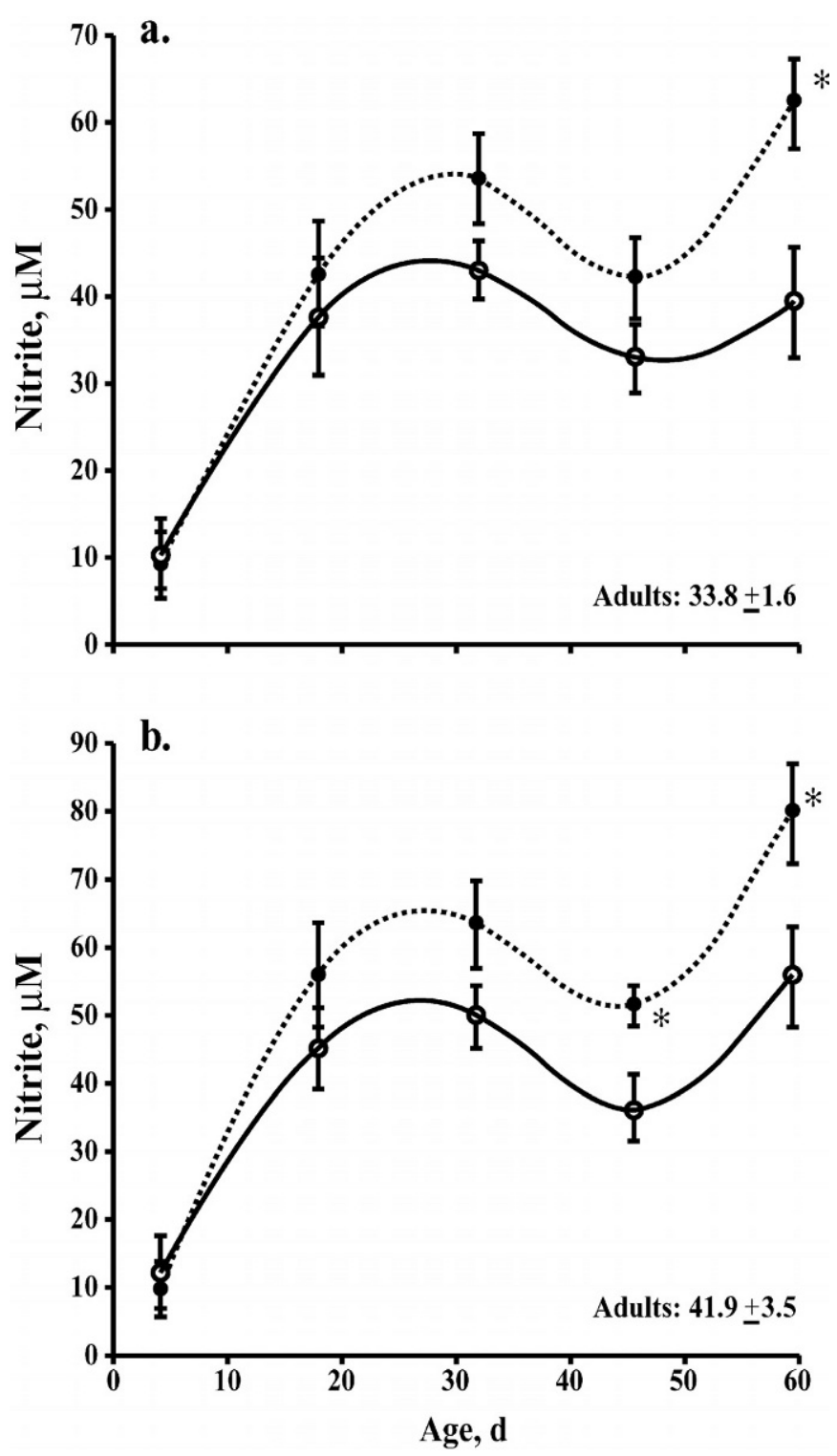

Figure 7. In vitro effects of the plane of nutrition mitogen-induced nitrite produced by peripheral blood mononuclear cells (PBMC) from milk replacer-fed calves. Nitrite is the stable product of the oxidation of nitric oxide, and the amount of nitrite present in culture supernatants is indicative of the amount of nitric oxide produced by the PBMC. Mean ( \pm SEM) responses of PBMC from control (-O-) and high plane of nutrition calves (-)-) to pokeweed mitogen (a) and concanavalin A (b) are shown. Asterisk indicates control and treatment means differed $(P<0.05)$ on that specific day. Corresponding responses of adults (mean $\pm \mathrm{SEM}, \mathrm{n}=6$ ) PBMC are shown in the lower right hand corner of each panel.

function were estimated using IgM, IFN- $\gamma$, and NO assays, respectively. Individually or in combination, these assays have been used to evaluate functional capacities of PBMC from young and adult dairy cattle (Ametaj et al., 1996; Rajaraman et al., 1997; Nonnecke et al., 2003). 
Effects of dietary protein and energy on immune function have been documented (reviewed by Woodward, 1998). The general responsiveness of $T$ cell subsets to stimulation with mitogen and antigen is reduced during protein energy malnutrition. Results from the present study indicate that the general responsiveness of PBMC populations from young calves to mitogenic stimulation was unaffected by the increased plane of nutrition provided by the intensified diet. Similarly, secretion of polyclonal IgM by mitogen-stimulated PBMC from TRT1 and TRT2 calves was comparable from 4 to $60 \mathrm{~d}$ of age. These results suggest that the industry standard MR may provide sufficient protein and energy to maintain the general responsiveness of PBMC population and T-dependent B cell responses of this population. Interestingly, responses of calf PBMC in these assays were substantially lower than responses of PBMC from adult cattle throughout the experimental period. Based on these data, functional maturation of the calf's PBMC population, as measured by proliferation and Ig secretion assays, did not appear to be promoted by the additional protein and energy provided by an intensified MR.

The $\mathrm{T}$ helper lymphocytes are defined by their distinctive functions and range of cytokines they produce in response to antigenic stimulation (Mosmann and Coffman, 1989). The T helper 1 response, characterized primarily by the production of IFN- $\gamma$, is crucial for effective cell-mediated responses to infection by intracellular pathogens. Interferon- $\gamma$ produced by mitogen- or antigen-stimulated T cells and NK cells can lead to the activation of monocytes/macrophages resulting in the release of $\mathrm{NO}$ and its derivatives. The production of NO plays a pivotal role in the regulation of physiological processes, host defense, inflammation, and immunity. Leukocytes from both TRT1 and TRT2 calves produced substantially less IFN- $\gamma$ than PBMC from adult cattle. In contrast, NO responses of calf PBMC were comparable to or exceeded responses of PBMC from adult cattle. Rajaraman et al. (1998) also showed that resting and mitogen-stimulated PBMC from MR-fed calves produce less IFN- $\gamma$ and more NO than parallel cultures of adult PBMC. They suggested that the age-related differences in NO and IFN- $\gamma$ secretion might be attributable to the immaturity of the neonatal immune system.

In the present study, responses of calf PBMC populations in IFN- $\gamma$ and NO assays appeared to be modulated by the plane of nutrition. Relative to responses of calves fed the traditional MR, calves fed the intensified MR demonstrated reduced IFN- $\gamma$ responses and elevated NO responses during the latter stages of the study. The elevation in NO production and concomitant reduction in IFN- $\gamma$ response may have been a consequence of feedback inhibition of IFN- $\gamma$ secretion by the robust NO response. Although these results are preliminary, they suggest that the plane of nutrition modulates IFN- $\gamma$ and NO production by PBMC from young calves. Diet-induced alterations of these pivotal functions might influence cell-mediated immune responses pivotal in the destruction of intracellular pathogens.

The elevated NO responses of PBMC from TRT2 calves relative to responses of PBMC from adult cattle should be noted given the potential for excess production of $\mathrm{NO}$ and NO derivatives (i.e., peroxynitrite and reactive nitrogen intermediates) to cause local and systemic damage (Wong and Billiar, 1995; Szabo, 2003). Potentially negative effects of excess $\mathrm{NO}$ production include vasodilation, edema, cytotoxicity, and the mediation of cytokine-dependent processes that can lead to tissue destruction (Abramson et al., 2001). The late occurrence of the elevated NO responses of TRT2 calves suggests that weaning at 5 to $6 \mathrm{wk}$ rather than at 7 to $8 \mathrm{wk}$ might reduce or preclude potentially negative consequences associated with aberrant NO production. Alternatively, the robust NO responses of PBMC from calves fed an intensified MR may provide additional protection against intracellular pathogens during a period of life characterized by an increased risk of infection. If this assumption were valid, then the effects of feeding an intensified MR on this specific aspect of immune function would be beneficial to the calf. These results also suggest that judging the immunocompetency of the neonate based on the composition and function of adult PBMC population may need to be reevaluated. New studies considering in vivo approaches to evaluate immune and metabolic function are needed to establish or confirm the effects of the plane of nutrition on the immunocompetency of the neonatal calf.

\section{CONCLUSIONS}

Results from the present study confirm the growthpromoting benefits of feeding an intensified MR to dairy calves. Although feeding an intensified MR to dairy calves promotes lean body growth, effects of the elevated plane of nutrition on immune variables examined in the present study were minimal. The number of circulating leukocytes and the composition of the PBMC population as well as this population's general responsiveness and capacity to secrete IgM were not affected by diet. Results from ex vivo assays of cell function, however, suggest that the plane of nutrition may modulate functions intimately associated with cell-mediated immune responses. Because of the inherent limitations of ex vivo cell function assays, in vivo studies incorporating experimentally induced adaptive immune responses or inflammation are necessary to fully understand the immunological consequences of feeding an intensified MR to neonatal calves. 


\section{ACKNOWLEDGMENTS}

The authors thank Donald McDorman and Nancy Eischen in the Periparturient Disease of Cattle Research Unit, National Animal Disease Center and Amy Bork at Cornell University for technical support. The authors thank Milk Specialties, Co. (Dundee, IL) for their donation of milk replacer, with special thanks to Douglas Waterman and Troy Scott.

\section{REFERENCES}

Abramson, S. B., A. R. Amin, R. M. Clancy, and M. Attur. 2001. The role of nitric oxide in tissue destruction. Best Pract. Res. Clin. Rheumatol. 15:831-845.

Ametaj, B. N., D. C. Beitz, T. A. Reinhardt, and B. J. Nonnecke. 1996. 1,25-Dihydroxyvitamin $\mathrm{D}_{3}$ inhibits secretion of interferon- $\gamma$ by mitogen- and antigen-stimulated bovine mononuclear leukocytes. Vet. Immunol. Immunopathol. 52:77-90.

Bartlett, K. S. 2001. Interactions of protein and energy supply from milk replacers on growth and body composition of dairy calves. M.S. Thesis. Univ. of Illinois, Urbana-Champaign.

Bielefeldt-Ohmann, H., L. G. Filion, and L. A. Babiuk. 1983. Bovine monocytes and macrophages: An accessory role in suppressor-cell generation by Con A and in lectin-induced proliferation. Immunology 50:189-197.

Blome, R. 2002. Growth, nutrient utilization, and body composition of dairy calves fed milk replacers containing different amounts of protein. M. S. Thesis. Univ. of Illinois, Urbana-Champaign.

Chandra, R. K. 1982. Numerical and functional deficiency in T helper cells in protein energy malnutrition. Clin. Exp. Immunol. $51: 126-132$.

Clark, R. 1997. The somatogenic hormones and insulin-like growth factor-1: Stimulator of lymphopoiesis and immune function. Endocrine Rev. 18:157-179.

Diaz, M. C., M. E. Van Amburgh, J. M. Smith, J. M. Kelsey, and E. L. Hutton. 2001. Composition of growth of Holstein calves fed milk replacer from birth to $105 \mathrm{~kg}$ body weight. J. Dairy Sci. 84:830-842.

Dore, M., D. O. Slauson, and N. R. Nielson. 1991. Decreased respiratory burst activity in neonatal bovine neutrophils stimulated by protein kinase C. Am. J. Vet. Res. 52:375-380.

Franklin, S. T., J. W. Young, and B. J. Nonnecke. 1994. Proliferation and phenotype of bovine mononuclear leukocytes in cultures stimulated by pokeweed mitogen. J. Dairy Sci. 77:3592-3600.

Green, L. C., D. A. Wagner, J. Glogowski, P. L. Skipper, J. S. Wishnok, and S. R. Tannenbaum. 1982. Analysis of nitrate, nitrite, and [15N]nitrate in biological fluids. Anal. Biochem. 126:131-138.

Hein, W. R., and C. R. Mackay. 1991. Prominance of $\gamma \delta$ T cells in the ruminant immune system. Immunol. Today 34:30-35.

Higuchi, H., H. Nagahata, M. Hiroki, and H. Noda. 1997. Relationship between age-dependent changes in bovine neutrophil functions and their intracellular $\mathrm{Ca}^{2+}$ concentrations. J. Vet. Med. Sci. 59:271-276.

Kooijman, R., E. L. Hooghe-Peters, and R. Hooghe. 1996. Prolactin, growth hormone, and insulin-like growth factor-1 in the immune system. Adv. Immunol. 63:377-454.

Macallan, D. C. 1999. Malnutrition and tuberculosis. Diagn. Microbiol. Infect. Dis. 34:153-157.

Menge, C, B. Neufeld, W. Hirst, R. Bauerfeind, G. Baljer, and L. H. Wieler. 1999. Phenotypcial characterization of peripheral blood leukocytes in the newborn calf. J. Vet. Med. B. 46:559-565.

Mosmann, T. R., and R. L. Coffman.1989. TH1 and TH2 cells: Different patterns of lymphokine secretion lead to different functional properties. Annu. Rev. Immunol. 7:145-173.
Nagahata, H., N. Kajima, I. Higashitani, H. Ogawa, and H. Noda. 1991. Postnatal changes in lymphocyte function of dairy calves. J. Vet. Med. 38:49-54.

National Research Council. 2001. Pages 214-233 in Nutrient Requirements of Dairy Cattle. 7th rev. ed.. Natl. Acad. Sci., Washington, DC.

Nonnecke B. J., S. T. Franklin, and S. L. Nissen. 1991. Leucine and its catabolites alter mitogen-stimulated DNA synthesis by bovine lymphocytes. J. Nutr. 121:1665-1672.

Nonnecke, B. J., S. T. Franklin, T. A. Reinhardt, and R. L. Horst 1993. In vitro modulation of proliferation and phenotype of resting and mitogen-stimulated bovine mononuclear leukocytes by 1,25 dihydroxyvitamin $\mathrm{D}_{3}$. Vet. Immunol. Immunopathol. 38:75-89.

Nonnecke, B. J., and R. L. Horst. 1992. 1,25-Dihydroxyvitamin D3 enhancement of in vitro immunoglobulin secretion by mitogenstimulated bovine peripheral blood lymphocytes. Immunol. Infect. Dis. 2:185-189.

Nonnecke, B. J., R. L. Horst, W. R. Waters, P. Dubeski, and J. A. Harp. 1999. Modulation of fat-soluble vitamin concentrations and blood mononuclear leukocyte populations in milk replacer-fed calves by dietary vitamin $\mathrm{A}$ and $\beta$-carotene. J. Dairy Sci. 82:2632-2641.

Nonnecke, B. J., W. R. Waters, M. R. Foote, R. L. Horst, M. A. Fowler, and B. L. Miller. 2003. In vitro effects of 1,25-dihydroxyvitamin $\mathrm{D}_{3}$ on interferon- $\gamma$ and tumor necrosis factor- $\alpha$ secretion by blood leukocytes from young and adult cattle sensitized with Mycobacterium bovis BCG. Int. J. Vit. Nutr. Res. 73:235-244.

Rajaraman, V., B. J. Nonnecke, and R. L. Horst. 1997. Effects of replacement of native fat in colostrum and milk with coconut oil on fat-soluble vitamins and immune function in calves. J. Dairy Sci. 81:2380-2390.

Rajaraman, V., B. J. Nonnecke, S. T. Franklin, D. C. Hammell, and R. L. Horst. 1998. Effects of vitamins A and $\mathrm{E}$ on nitric oxide production by blood mononuclear leukocytes from neonatal calves fed milk replacer. J. Dairy Sci. 81:3278-3285.

Senogles, D. R., P. S. Paul, C. C. Muscoplat, and D. W. Johnson. 1978. Ontogeny of circulating B lymphocytes in neonatal calves. Res. Vet. Sci. 25:34-36.

Smith, J. M., M. E. Van Amburgh, M. C. Diaz, M. C. Lucy, and D. E. Bauman. 2002. Effect of nutrient intake on the development of the somatotropic axis and its responsiveness to $\mathrm{GH}$ in Holstein bull calves. J. Anim. Sci. 80:1528-1537.

Szabo, C. 2003. Multiple pathways of peroxynitrite cytotoxicity. Toxicol. Lett. 140:105-112.

ten Bruggencate, S. J. M., L. M. Hillyer, and B. D. Woodward. 2001. The proportion of CD45RA+CD62L+ (quiesecent-phenotype) T cells within the $\mathrm{CD}^{+}$subset increases in advanced weight loss in the protein- or energy-deficient weanling mouse. J. Nutr. 131:32663269 .

Tikofsky, J. N., M. E. Van Amburgh, and D. A. Ross. 2001. Effect of varying carbohydrate and fat levels on body composition of milk replacer-fed calves. J. Anim. Sci. 79:2260-2267.

Wilson, R. A., A. Zolnai, P. Rudas, and L. V. Frenyo. 1996. T-cell subsets in blood and lymphoid tissues obtained from fetal calves, maturing calves, and adult bovine. Vet. Immunol. Immunopathol. 53:49-60.

Wong, J. M., and T. R. Billiar. 1995. Regulation and function of inducible nitric oxide synthase during sepsis and acute inflammation. Adv. Pharmocol. 34:155-170.

Woodward, B. 1998. Protein, calories, and immune defenses. Nutr. Rev. 56:S84-S92.

Woodward, B., L. Hillyer, and K. Hunt. 1999. T cells with a quiescent phenotype (CD45RA+) are overabundant in the blood and involuted lymphoid tissue in wasting protein and energy deficiencies. Immunology 96:246-253.

Wyatt, C. A., C. Madruga, C. Cluff, S. Parish, M. J. Hamilton, W. Goff, and W. C. Davis. 1994. Differential distribution of $\gamma \delta$ T-cell receptor lymphocyte populations in blood and spleen of young and adult cattle. Vet. Immunol. Immunopathol. 40:187-199. 